\title{
MINERAÇÃO E SEU IMPACTO AMBIENTAL
}

E.Ribeiro Filho

A humanidade sempre consumiu bens minerais e deles ficou mais dependente com sua evolução cultural, cientffica e tecnológica. Se é verdade que a mineração constitui um dos meios do homem interferir no meio ambiente, desfigurando-o, degradando-o e poluindo-o, não é menos verdade que a mineração também representa um dos meios de suprir as necessidades das quais as sociedades modernas não podem mais abrir mão. Não nos ajustarlamos a viver sem consumir aço e concreto, alumínio, cobre, cimento, vidro, papel, carros, trens, aviões, TVs, computadores e tantos outros utensflios fabricados com bens minerais. Por outro lado, a agricultura moderna e adaptada à crescente população mundial, para satisfazer suas necessidades de alimento, exige produção crescente de corretivos dos solos, de fertilizantes inorgânicos fosfatados e potássicos, bem como dos micronutrientes minerais. Por tempo de duração ainda não previsivel a humanidade deverá conviver com o consumo de minérios convencionais, até que os novos produtos, pesquisados hoje pela Ciência e Engenharia dos Materiais (CEM), possamm substituítos parcial ou totalmente. Até as primeiras décadas do próximo século estaremos consumindo os combustíveis fósseis (petróleo, carvão, linhito, turfa e folhelho betuminoso), bem como todos os minérios imprescindiveis e necessários à humanidade. Utilizaremos quantidades crescentes de minérios necessários à produção de energia e até mesmo alguns dos minérios considerados de uso supérfluo terão mercado garantido.

Ainda que admitissemos uma tendência para controlar e conter o consumo de bens minerais ou para estabelecer tetos de consumo, o simples aumento da população mundial, que deverá atingir 6.300 milhões de habitantes no ano 2.000 , provocaria demanda maior de todos os minérios e das fontes de energia.

A mineração que sempre constituiu uma das ações com as quais o homem

Departamento de Geologia Econômica e Geofísica Aplicada, Instituto de Geociências, USP. 
interfere no meio ambiente, continuará sendo um processo ativo de agressão e degradação ambiental. Este processo que se inicia na fase de prospecção, progride com a pesquisa, é crescente durante a lavra e beneficiamento dos minérios, mas prossegue até o abandono da jazida.

Eliminando-se o exagero com que ecologistas fanáticos $\theta$ a mídia estão se manifestando sobre problemas ambientais, a verdade é que a humanidade em geral, empresários, polfticos, naturalistas, pesquisadores e cientistas estão despertando e aguçando a sensibilidade e bom senso para perceber que pode haver compatibilidade entre o uso adequado de minérios e a mitigação do impacto ambiental causado pela mineação.

$O$ afamado escritor e pensador E. Hemingway afirmou: "Um continente envelhece depressa assim que nós chegamos". A mineração tem sido responsável por uma razóavel parcela do envelhecimento de algumas regiōes do Brasil.

As leis, decretos, EIA, RIMA, Institutos e Secretarias deveriam garantir a compatibilidade desejada entre Mineração, Conservação e Meio Ambiente. Entretanto, a experiência brasileira tem demonstrado que mais do que normas formais deverá prevalecer a compreensão e colaboração das empresas de mineração, que farão com que a reabilitação ambiental tenha seus custos embutidos nos investimentos de seus projetos, desde a fase de pesquisa até a implantação e abandono das atividades minerárias. Aos órgãos competentes, além da tarefa de estabelecer a política mineral do pals, caberão também aquelas de controlar e fiscalizar as atividades de mineração em todas as suas fases e a de estabelecer a ordenação e/ou zoneamento territorial de acordo com a atividade econômica a ser implantada. Se a estas iniciativas, e a elas atreladas, houver um programa educativo relativo à ciência ambiental, é possivel que não sejamos os insensatos causadores do envelhecimento rápido do solo e subsolo do Brasil, ao chegarmos com o machado que fere; a motoserra que derruba; a queimada que destroi; a chama que queima; os agrotóxicos que envenenam; as chaminés que poluem; os taludes que deslizam; os explosivos que abalam e fraturam; a poeira que sufoca; o ar impuro que asfixia; o petróleo que empobrece os mares e contamina praias; a silicose que petrifica; com os metais pesados que envenenam os rios ou com o mercúrio que mata. 